\title{
Pengaruh Paparan Cahaya Matahari Pagi Terhadap Penurunan Berat Badan dan Body Fat Wanita Dewasa Muda Obesitas di Asrama Putri STIKES Medistra Indonesia
}

\author{
Linda Kristiani Telaumbanua, ${ }^{1}$ Kusnandi Rusmil, ${ }^{2}$ Yuni S. Pratiwi, ${ }^{3}$ Farid Husin, ${ }^{4}$ Ieva B. Akbar, \\ Hadyana Sukandar. ${ }^{6}$ \\ ${ }^{1}$ Mahasiswa Program Studi Magister Kebidanan Fakultas Kedokteran Universitas Padjadjaran \\ 2 Departemen Ilmu Kesehatan Anak Fakultas Kedokteran Universitas Padjadjaran \\ ${ }^{3,5}$ Departemen Fisiologi Fakultas Kedokteran Universitas Padjadjaran \\ ${ }^{4,6}$ Departemen Epidemiologi dan Biostatistika Fakultas Kedokteran Universitas Padjadjaran
}

\begin{abstract}
Abstrak
Obesitas adalah penyakit yang berkontribusi terhadap komplikasi metabolik. Prevalensi obesitas pada wanita ditemukan lebih tinggi dari laki-laki dengan kecenderungan meningkat dari tahun ke tahun. Dampak obesitas terhadap wanita telah banyak ditemukan, khususnya komplikasi kehamilan dan persalinan serta janin yang dilahirkan. Untuk itu wanita didorong menurunkan berat badan pada masa pra-hamil. Beberapa penelitian menemukan ada hubungan kuat antara paparan cahaya matahari pagi dengan penurunan berat badan dan lemak tubuh, sehingga cahaya matahari dapat menjadi salah satu bagian dari terapi kombinasi. Rancangan penelitian ini adalah quasi eksperimental pre dan post di asrama putri STIKES Medistra Indonesia. Subjek terdiri dari 16 mahasiswa obesitas. Intervensi yang diberikan adalah paparan cahaya matahari pagi 45 menit setiap hari selama 21 hari berturut-turut dengan intensitas rata-rata 13.250 lux. Intensitas cahaya matahari diukur dengan lux meter. Berat badan dan body fat diukur dengan timbangan digital Bioelectrical Impedance Analysis (BIA). Data dianalisis dengan uji t, uji Mann-Whitney, dan uji Wilcoxon. Pengaruh paparan cahaya terhadap penurunan berat badan dan body fat diperoleh dari persentase selisih hasil pengukuran sebelum dan sesudah intervensi dilakukan. Pada kelompok perlakuan persentase penurunan berat badan sebesar $0,53 \%(p<0,05)$ dan penurunan body fat $1,02 \% \quad(\mathrm{p}<0,05)$. Simpulan penelitian ini adalah paparan cahaya matahari pagi terhadap wanita dewasa muda obesitas berpengaruh terhadap penurunan berat badan, body fat dan nafsu makan.
\end{abstract}

Kata kunci: berat badan, body fat, cahaya matahari pagi, obesitas. 


\title{
Impact of morning sun light exposure on the body weight and body fat loss in obese young women at the female dormitory of the STIKES Medistra Indonesia
}

\begin{abstract}
Obesity is a disease that contributes to the metabolic complications. The prevalence of obesity in women is higher than men and tends to increase. Impacts of obesity on women have been found, especially complications of pregnancy and childbirth also on the newborn fetus. Thus women are encouraged to lose weight in the pre-pregnancy period. Modification of diet is sometimes difficult if the environment is not supportive. Several studies have found significant association between morning sun light exposure and decreasing body weight and body fat which suggests morning sun light exposure as one of combined obesity therapy methods. This study was an experimental research with quasi experimental design with pre- and post-comparison in girls' dormitory of STIKES Medistra Indonesia. Subject consisted of 16 obese students. Given intervention was exposure to sunlight in the morning within 45 minutes for each of 21 consecutive days with an average intensity of 13,250 lux. Sunlight intensity was measured using a lux meter. Body weight was measured with digital scales and body fat by using Bioelectrical Impedance Analysis (BIA). Data were analyzed using t test, Mann-Whitney and Wilcoxon test. Sun exposure effect on body weight and fat decreases measured by percentage difference between pre and post intervention figures. In the intervention group, body weight and fat decreases by $0.53 \%$ and $1.02 \%$ respectively. This study concludes there exists the effect of morning sunlight exposure on body weight and body fat decrease.
\end{abstract}

Keywords: Weight, body fat, morning sunlight, obesity.

\section{Pendahuluan}

Prevalensi kelebihan berat badan dan obesitas meningkat sangat tajam di seluruh dunia dan mencapai tingkatan yang membahayakan. Obesitas juga dikaitkan dengan peningkatan risiko kematian. ${ }^{1}$ Pada tahun 2010, kelebihan berat badan dan obesitas diperkirakan menyebabkan 3,4 juta kematian di dunia. ${ }^{2,3}$ Menurut data prevalensi di negara maju maupun negara berkembang obesitas umumnya lebih sering terjadi pada wanita dibanding pria. Demikian halnya data Riset Kesehatan Dasar (Riskesdas) di Indonesia yang juga melaporkan prevalensi obesitas pada wanita dewasa $>18$ tahun menunjukkan peningkatan dari tahun ke tahun. ${ }^{4}$ Beberapa dampak obesitas pada kehamilan wanita telah diteliti berhubungan dengan peningkatan komplikasi kehamilan. ${ }^{5}$

Sejumlah neurohormon yang terlibat dalam pengaturan nafsu makan dan berat badan antara lain insulin, leptin, ghrelin, melatonin, dan serotonin. ${ }^{6}$ Peran hormonhormon tersebut telah banyak diteliti berhubungan dengan metabolisme tubuh yang terkait dengan berat badan, komposisi lemak tubuh, dan asupan makanan. Modifikasi gaya hidup merupakan sebuah strategi standar pengelolaan pada penderita obesitas yaitu dengan cara menghindari asupan berlebihan energi tinggi dan makanan rendah gizi serta meningkatkan aktivitas fisik. Akan tetapi modifikasi gaya hidup tersebut terkadang sulit dilakukan bila lingkungan sangat tidak mendukung. ${ }^{7}$

Beberapa dari hasil penelitian merekomendasikan bahwa cahaya matahari pagi memiliki peran dalam metabolisme dan regulasi berat badan, sehingga dapat dijadikan sebagai terapi kombinasi penurunan berat badan pada penderita obesitas. Cahaya matahari diketahui juga dapat memodulasi konsentrasi leptin yang berdampak pada pengurangan asupan makanan. ${ }^{8,9}$ Reseptor neurohormon termasuk leptin dan serotonin adalah target utama untuk nafsu makan yang dipengaruhi cahaya, dengan demikian menjadi sasaran pengembangan terapi untuk memerangi obesitas. $^{9-12}$

Pentingnya pelayanan dan perhatian bidan terhadap obesitas pada wanita dewasa masa sebelum hamil juga didorong oleh sebuah 
hasil penelitian prospektif yang menemukan banyak wanita obesitas pada kunjungan antenatal pertama mereka. Telah didapatkan bukti bahwa obesitas pada masa sebelum hamil menunjukkan status vitamin D yang rendah pada wanita dan neonatus mereka. ${ }^{5}$

Laporan penelitian mengemukakan bahwa prevalensi obesitas lebih banyak terjadi di daerah urban $(51 \%)$ dari pada rural (38\%), hal ini dikarenakan adanya kemudahan akses terhadap pangan dan transportasi seperti tersedianya makanan siap saji yang tinggi kalori dan alat transportasi yang sering menggunakan kendaraan bermotor. ${ }^{13}$ STIKes Medistra Indonesia adalah salah satu institusi pendidikan di Kota Bekasi dimana Kota Bekasi merupakan salah satu daerah urban. Dari hasil survei pendahuluan diketahui bahwa setiap tahunnya terjadi peningkatan jumlah mahasiswi yang mengalami obesitas Berdasarkan hal tersebut di atas dan mengingat penelitian ini belum pernah dilakukan maka penulis tertarik dan berkeinginan melakukan penelitian tentang pengaruh paparan cahaya matahari pagi terhadap penurunan berat badan dan body fat wanita dewasa muda obesitas.

\section{Metode}

Penelitian ini adalah penelitian eksperimen yang dilakukan dengan rancangan quasi exsperimental (ekperimen semu) pre- dan post- dengan pembanding. Populasi adalah semua wanita dewasa muda dengan status obesitas di asrama putri STIKes Medistra Indonesia Kota Bekasi. Sampel dalam penelitian ini adalah mahasiswi dengan obesitas memenuhi kriteria inklusi sebagai berikut: a) Subjek penelitian adalah mahasiswi STIKES Medistra Indonesia dengan BMI $\geq 27 \mathrm{~kg} / \mathrm{m}^{2}$, b) Umur $19-22$ tahun, c) Subjek dalam keadaan sehat berdasarkan hasil anamnesis dan pemeriksaan fisik (tekanan darah, nadi, suhu, dan pernafasan), d) Bersedia mengikuti program kegiatan secara penuh.

Kriteria ekslusi penelitian ini adalah: a). Mengundurkan diri di tengah-tengah masa program kegiatan berlangsung, b) Tidak memenuhi kehadiran $90 \%$ pada program kegiatan paparan, c) Menderita sakit berat di tengah-tengah masa program kegiatan. Kelompok perlakuan menerima paparan cahaya >1300 lux dan kelompok kontrol adalah subjek dengan paparan cahaya pagi $<1300$ lux.

Variabel utama yang akan diukur dalam penelitian ini adalah berat badan dan body fat dengan menggunakan timbangan digital Omron HBF 358 dengan ketelitian $0,1 \mathrm{~kg}$ untuk mengukur berat badan, dan sekaligus menggunakan teknik Bioelectrical Impedence Analysis (BIA) pada alat tersebut dengan tingkat ketelitian $0,1 \%$ untuk mengukur body fat. Intensitas cahaya matahari pagi diukur dengan menggunakan Lux meter Lutron LX103.

Penelitian memperhatikan aspek etik, prinsip sukarela serta persetujuannya (informed consent), menghormati harkat dan martabat manusia dengan mengatasi dan meminimalkan ketidaknyamanan subjek. Penelitian ini bertujuan untuk menganalisis pengaruh paparan cahaya matahari pagi terhadap penurunan berat badan dan body fat wanita dewasa muda obesitas di asrama putri Stikes Medistra Indonesia

\section{Hasil}

Penelitian tentang pengaruh paparan sinar matahari pagi telah dilakukan terhadap 32 mahasiswi STIKes Medistra Indonesia dengan status gizi obesitas. Subjek penelitian ini terbagi ke dalam dua kelompok, yakni kelompok perlakuan (kelompok A) mendapat perlakuan berjemur pada pagi hari yaitu pukul 06.45 WIB sampai dengan pukul 07.30 WIB dengan intensitas >1300 lux (rata-rata intensitas 13.249 lux) selama 21 hari, sedangkan kelompok kontrol (kelompok B) di dalam asrama saja dengan rata-rata intensitas dalam ruangan sebesar 325 lux. Awalnya kelompok perlakuan sebanyak 17 orang, tetapi 1 orang drop out karena tidak menghadiri kegiatan paparan selama 3 hari berturut-turut. Demikian halnya dengan kelompok kontrol, awalnya adalah 17 orang, namun 1 orang mengalami demam tifoid, maka peserta tersebut drop out dari penelitian. Sehingga jumlah subjek yang diukur dan dianalisis dalam penelitian ini adalah 16 orang pada masing-masing kelompok. Jumlah ini masih memenuhi jumlah kriteria perhitungan sampel yaitu minimal 14 orang.

Pada tahap analisis data, langkah pertama uji normalitas data untuk data numerik dengan 
uji Shapiro Wilk, jika diperoleh nilai $\mathrm{p}<0,05$ artinya data tidak berdistribusi normal, nonparametrik. Nilai $p$ nya $>0,05$ artinya data berdistribusi normal, dan uji statistik adalah parametrik. Hasil penelitian disajikan dalam tabel berikut:

Tabel 1. Data Dasar Karakteristik Subjek Penelitian (Data Pre)

\begin{tabular}{llll}
\hline \multirow{2}{*}{\multicolumn{1}{c}{ Karakteristik }} & \multicolumn{2}{c}{ Kelompok } & \multirow{2}{*}{ Nilai p ${ }^{*}$} \\
\cline { 2 - 3 } & \multicolumn{1}{c}{$\begin{array}{c}\text { Perlakuan } \\
(\mathbf{n = 1 6})\end{array}$} & $\begin{array}{c}\text { Kontrol } \\
(\mathbf{n = 1 6})\end{array}$ & \\
\hline Umur (tahun) & $19,1(0,3)^{* *}$ & $19,4(0,5)$ & 1,000 \\
Tinggi badan $(\mathrm{cm})$ & $155,9(4,4)$ & $154,7(4,8)$ & 0,483 \\
Berat badan $(\mathrm{kg})$ & $79,3(10,3)$ & $79,8(11,3)$ & 0,885 \\
Indeks massa tubuh $(\mathrm{kg} / \mathrm{m} 2)$ & $32,5(3,1)$ & $33,3(3,8)$ & 0,520 \\
Body fat $(\%)$ & $36,9(2,4)$ & $38,0(2,8)$ & 0,234 \\
\hline
\end{tabular}

Keterangan : *) berdasarkan uji t **) nilai rerata dan simpang baku.

Dari data karakteristik subjek didapatkan baik kelompok perlakuan (kelompok A) maupun kelompok kontrol (kelompok B) memiliki IMT/BMI rata-rata lebih dari 30 $\mathrm{kg} / \mathrm{m}^{2}$. Sedangkan rata-rata body fat peserta pada kedua kelompok juga termasuk dalam kategori tinggi (>30\%). Dari hasil pengukuran awal sebelum intervensi diberikan, tampak semua variabel menunjukkan ada perbedaan yang bermakna sehingga semua data dasar homogen dan layak untuk diperbandingkan.

Tabel 2. Perbedaan Pengaruh Paparan Cahaya Matahari Pagi pada Berat Badan dan Body Fat Pre- dan Post- pada Wanita Dewasa Muda Obesitas

\begin{tabular}{lccc}
\hline \multirow{2}{*}{ Variabel } & \multicolumn{2}{c}{ Pengamatan } & \multirow{2}{*}{ Nilai p ${ }^{*}$} \\
\cline { 2 - 3 } $\begin{array}{l}\text { Kelompok Intervensi } \\
\text { Berat badan (kg) } \\
\quad \text { Mean (SD) }\end{array}$ & \multicolumn{2}{c}{ Pre } & \\
$\begin{array}{l}\text { Body fat (\%) } \\
\quad \text { Mean (SD) }\end{array}$ & $79,3(10,3)$ & $78,8(10,1)$ & 0,013 \\
$\begin{array}{l}\text { Kelompok Kontrol } \\
\text { Berat badan (kg) } \\
\quad \text { Mean (SD) }\end{array}$ & $36,9(2,4)$ & $36,6(2,6)$ & 0,082 \\
$\begin{array}{l}\text { Body fat (\%) } \\
\quad \text { Mean (SD) }\end{array}$ & $79,8(11,3)$ & $80,0(11,2)$ & 0,556 \\
\hline
\end{tabular}

Keterangan : *) berdasarkan Uji t berpasangan

Tabel di atas memperlihatkan bahwa berat badan pada kelompok intervensi menunjukkan penurunan dan perbedaan bermakna. Tidak demikian halnya dengan body fat. Akan tetapi karena penelitian ini mengetengahkan hipotesis adanya penurunan berat badan dan body fat dari pengaruh paparan cahaya matahari pagi, maka yang diperbandingkan persentase penurunannya pre- ke post- intervensi, dan hasilnya dapat terlihat pada tabel 3 berikut ini.

Tabel 3. Perbedaan Pengaruh Paparan Cahaya Matahari Pagi pada Berat Badan, dan Body Fat Pre- dan Post- pada Wanita Dewasa Muda Obesitas

\begin{tabular}{|c|c|c|c|}
\hline \multirow{2}{*}{$\begin{array}{c}\text { Variabel } \\
(\% \text { rata-rata penurunan })^{*}\end{array}$} & \multicolumn{2}{|c|}{ Kelompok } & \multirow[b]{2}{*}{ Nilai $\mathbf{p}^{*}$} \\
\hline & $\begin{array}{c}\begin{array}{c}\text { Perlakuan } \\
(\mathrm{n}=16)\end{array} \\
\end{array}$ & $\begin{array}{l}\text { Kontrol } \\
(\mathrm{n}=16)\end{array}$ & \\
\hline Berat badan & 0,53 & $-0,16$ & 0,039 \\
\hline Body fat & 1,02 & $-0,03$ & 0,029 \\
\hline
\end{tabular}

Keterangan : $*)$ dihitung dari rumus $\%$ turun $=100 *($ data pre-data post -$) /$ data pre-

**) berdasarkan Uji t; kecuali untuk skor body fat dan asupan energi dengan uji MannWhitney 
Perbandingan persentase penurunan berat badan dan body fat menunjukkan hasil yang bermakna. Selisih ini sudah memperhitungkan perbandingannya dengan nilai awal sebelum perlakuan diberikan. Kemudian dicari ratarata dari selisih tersebut lalu disajikan dalam bentuk persentase. Walaupun besaran penurunannya relatif kecil atau tidak signifikan dibandingkan berat badan awal tetapi probabilitas penurunan berat badan adalah signifikan dengan paparan cahaya matahari pagi. Penelitian lebih lanjut diperlukan untuk frekuensi paparan yang reguler dengan periode yang lebih lama untuk mendapatkan penurunan yang lebih banyak.

\section{Pembahasan}

Program paparan yang dilaksanakan selama 21 hari tersebut di bawah kondisi cuaca cerah sebanyak 19 hari dan kondisi cuaca mendung sebanyak 3 hari. Akan tetapi pada kondisi cuaca mendung sekalipun, intensitas cahaya matahari masih bisa didapatkan pada rata-rata sebesar 8.230 Lux. Cuaca hujan tidak pernah terjadi selama program kegiatan berlangsung. Di bawah cuaca pagi yang cerah tersebut subjek kelompok perlakuan (kelompok A) melakukan aktivitas duduk secara bersamasama. Selama masa dan setelah program berlangsung tidak ada yang mengalami keluhan atau masalah kesehatan baik di kulit maupun di mata. Setelah 45 menit program berlangsung, maka peserta menjalani aktivitas perkuliahan. Aktivitas yang dijalani sepanjang hari di lingkungan kampus dan asrama dilakukan di bawah intensitas cahaya $<1300$ Lux. Rata-rata intensitas cahaya dalam ruangan (indoor) lingkungan asrama 369,5 Lux, dan lingkungan kampus 305,5 Lux. Jumlah intensitas tersebut bersumber dari pencahayaan lampu dan cenderung tetap, atau tidak pernah mencapai di atas 1300 Lux walaupun pada kondisi cuaca cerah. Aspek cahaya indoor ini turut diperhatikan untuk memastikan para peserta tidak terpapar cahaya yang berintensitas tinggi sepanjang pagi dan sepanjang hari. Sehingga untuk tempat-tempat di luar ruangan yang sering dilewati oleh para peserta seperti halaman kampus, jalan raya, dianjurkan para peserta mengenakan jaket dengan warna yang memantulkan cahaya (berwarna putih) dan tidak berlama-lama di tempat tersebut. Jumlah intensitas cahaya di luar ruangan tanpa atap atau pelindung sifatnya mengikuti jumlah intensitas cahaya matahari yaitu semakin tinggi di siang hari dan semakin rendah menjelang sore hari. Mencermati jumlah paparan cahaya matahari pagi yang diterima peserta adalah sebesar 13.249 Lux, maka besaran rata-rata intensitas ini jauh melebihi rata-rata intensitas penelitian yang pernah dilakukan di Eropa dan Amerika. Penelitian Kathryn et al yang menggunakan sumber cahaya ambient atau cahaya sekitar sepanjang waktu, yang diukur dengan alat Actiwatch di luar pakaian setiap saat. ${ }^{10}$ Sumber cahaya penelitian Danilenko dll adalah dioda pemancar cahaya (LED) dihasilkan cahaya putih dengan panjang gelombang biru dengan intensitas 1.300 Lux pada jarak $41 \mathrm{~cm}$. Penelitian Dunai menggabungkan antara paparan cahaya buatan (5000 Lux) dengan latihan/ olah raga ringan. ${ }^{11}$

Penelitian ini mengandalkan cahaya alami matahari. Keunggulan matahari sebagai cahaya alami yang tersedia di daerah tropis diketahui bermanfaat dalam sintesis vitamin D dalam tubuh, dan Indonesia mempunyai potensi energi matahari tersedia melimpah, gratis, spektrum cahaya lengkap, memiliki daya panas, dan kimiawi bagi pembentukan vitamin D dan dinamis.

Penelitian Kathyrin dkk menghasilkan penurunan BMI pada subjek dari 7 hari saja. ${ }^{10}$ Akan tetapi pada penelitian Kathryn, berat badan dan tinggi badan didapatkan dari laporan peserta, bukan dari pengukuran langsung kepada subjek. Dalam penelitian Danilenko dkk, memberi hasil penurunan signifikan dari persen lemak tubuh, massa lemak dan nafsu makan, sedangkan penurunan berat badan tidak banyak perbedaan. ${ }^{11}$ Perbandingan berat badan dan body fat antara kelompok paparan cahaya dan plasebo yakni penurunan berat badan sebesar $0,33 \mathrm{~kg}$ dan penurunan body fat sebesar $0,31 \%$. Hasil tersebut memperlihatkan bahwa sedikit sekali penurunan berat badan dihasilkan. Penelitian oleh Dunai dkk memberi hasil bahwa subjek obesitas pada kelompok cahaya mengalami penurunan BMI yang signifikan setelah 6 minggu program kegiatan. Akan tetapi penurunan BMI pada penelitian Dunai tersebut tidak membuat BMI 
subjek kembali ke keadaan normal/ tidak obes. $^{12}$

Penurunan berat badan dan body fat sebagai pengaruh dari paparan cahaya matahari pagi dapat disebabkan efek paparan cahaya yang masuk melalui jalur mata dan kulit. Sasaran utama pengaruh cahaya yang telah diteliti yang berhubungan dengan berat badan individu adalah melalui mekanisme kerja serotonin dan leptin di dalam tubuh. Akan tetapi untuk memastikan kemungkinan perubahan hormon tersebut perlu pemeriksaan yang mendalam terhadap jumlah hormon tubuh peserta penelitian.

Pada tanggal 04 September 2015, peneliti kembali mengukur berat badan dan body fat peserta kelompok A untuk mengetahui apakah efek paparan cahaya matahari masih berpengaruh pada berat badan dan body fat subjek pasca setelah kurang lebih 4 bulan tidak menerima paparan cahaya lagi. Dari hasil pengukuran diperoleh rata-rata berat badan sebesar 80,09 $\mathrm{kg}$ dan rata-rata body fat sebesar 37,19\%. Dari hasil evaluasi di atas menunjukkan terjadinya peningkatan berat badan dan body fat setelah kurang lebih 4 bulan subjek tidak menerima paparan cahaya matahari pagi seperti kondisi saat penelitian. Dari hasil ini terlihat bahwa tanpa paparan cahaya yang reguler, subjek memperoleh kembali berat badan dan body fat pada keadaan semula atau bahkan bisa bertambah.

Menurut Garvey WT dkk dalam Consensus Conference on Obesity bahwa penanganan terhadap obesitas adalah manajemen gaya hidup. ${ }^{14}$ Manajemen gaya hidup adalah landasan untuk pengobatan obesitas dan termasuk 3 komponen utama yaitu makan sehat dan pembatasan kalori, meningkatkan pengeluaran energi dari aktivitas fisik secara teratur (misalnya, latihan aerobik) 3 sampai 5 hari per minggu. Membatasi makanan dan meningkatkan aktivitas fisik bagi beberapa orang dapat menjadi suatu hal yang sulit dilakukan.

Satu hal yang menjadi kelebihan pada penelitian ini adalah tidak dilakukannya intervensi terhadap diet dan aktivitas subjek penelitian. Subjek tidak dianjurkan mengatur porsi makanan maupun aktivitas fisik. Penurunan berat badan dan body fat sepenuhnya didapatkan dari efek paparan cahaya matahari pagi ditambah lagi dengan temuan pada penurunan nafsu makan. Dari hasil yang ditunjukkan dalam penelitian ini maka paparan cahaya matahari pagi dapat menjadi pilihan metode kombinasi dengan metode penanganan standar bagi wanita obesitas yang menurunkan berat badan untuk mencapai status gizi yang baik dalam masa reproduksinya.

Beberapa hal yang menjadi keterbatasan dalam studi eksperimen semu ini adalah penelitian ini tidak menilai kandungan atau kadar hormon yang dipengaruhi oleh paparan cahaya matahari pagi pada wanita obesitas dan penelitian ini hanya dilaksanakan dalam waktu 21 hari (3 minggu), sehingga sedikit penurunan berat badan dan body fat yang diperoleh karena keterbatasan waktu dan biaya. Simpulan penelitian ini adalah paparan cahaya matahari pagi berpengaruh terhadap penurunan berat badan dan body fat wanita dewasa muda obesitas. Akan tetapi paparan selama 3 minggu tidak mencukupi untuk menghasilkan penurunan berat badan dan body fat yang permanen. Maka disarankan penelitian lebih lanjut untuk melihat lebih dalam pengaruh pada modulasi hormon pada penderita obesitas. Penurunan berat badan dan body fat relatif tidak besar maka paparan cahaya matahari dapat menjadi bagian yang tidak terpisahkan dari terapi obesitas lainnya dan dapat dikombinasi dengan terapi standar penanganan obesitas.

\section{Daftar Pustaka}

1. Dang M.N, Hashem B.E. The epidemiology of obesity. Gastroenterol Clin North Am. 2010; 39(1):1-7.

2. Marie $\mathrm{Ng}$, Fleming $\mathrm{T}$, Robinson $\mathrm{M}$, Blake $\mathrm{T}$, Nicholas G, Christopher M. Global, regional and national prevalence of overweight and obesity in children and adults during 1980-2013: a systematic analysis for the Global Burden of disease Study 2013. Lancet. 2014; 384(9945):766-81.

3. Katherine MF.,Carrol MD,Ogden CL,Curtin LR. Prevalence and trends in obesity among US adults, 1999-2008. JAMA. 2010; 303(3):235-41.

4. Litbangkes. Laporan Hasil Riset Kesehatan Dasar (Riskesdas) Indonesia tahun 2013 Jakarta; 2014.

5. Institute of Obstetricians \& Gynaecologists Royal College of Physicians of Ireland. Obesity and Pregnancy, Clinical Practice Guidline; 2013.

6. W.Sunil. Pathophysiology of obesity: Focused, cause-driven approach to control the epidemic. Global Advanced Research Journal (GARJPP). 2013; 2(1): 2-12. 
7. Soegih Rachmad, Wiramihardja, editor. Obesitas permasalahan dan terapi praktis. Jakarta: Sagung Seto; 2009.

8. Helen CT, Kay HJ, Stuart PP,Simon NA, Derk-Jan D. Daily and Seasonal Variation in the spectral composition of light exposure in humans. Chronobiology International.. 2009: 26(5): 854-66.

9. Mariana G.F, Barbara P, Mark SR. Light modulater leptin and ghrelin in sleep-restricted adults. Hindawi International J Endocrinology. 2012: 6 pages.

10. Kathryn JR, Giovanni S, Kelly GB, Jhon W, Joseph $\mathrm{K}$, Phyllis CZ. Timing and intensity of light correlate with body weight in adult. PLOS ONE. 2014; 9(4):1-11.

11. Danilenko KV, Svetlana VM, Ekaterina AP. Bright light for weight loss: results of a controlled crossover trial. Obesity Facts.. 2013; 6:28-38.
12. Dunai A, Marta N, Sharon AC, Leonid K, Andras K.,Robert L., dkk. Moderate exercise and bright light treatment in overweight and obese individuals. Obesity. 2007; 15(7):1749-57.

13. Mendez MA,Monteiro CA, Popkin BM. Overweight exceeds underweight among women in most developing countries. Am Clin Nutr. 2005; 81:714-21.

14. Garvey WT, Garber AJ, Mechanick JI, Bray GA, Jack SD, Einhorn D, American Association of Clinical Endocrinologists and American College of Endocrinology Consesus Conference on Obesity: Building an Evidence base for Comprehensive Action. Endocrine Practise. 2014; 20(9):956-76. 